https://doi.org/10.31470/2706-7904-2021-16-49-53

\title{
ПСИХОЛІНГВІСТИЧНИЙ АНАЛІЗ ПОЕТИЧНОЇ ЗБІРКИ ВІРИ ВОВК «МАНДАЛЯ» У ВИМІРІ РЕСУРСІВ РЕЗИЛІЕНСУ
}

\section{Psycholinguistic Analysis of the Poetic Collection «Mandala» by Wira Wovk in Dimension of Resilience Resources}

\author{
Halyna Handzilevska \\ Dr. Sc. in Psychology, Professor \\ National University of Ostroh Academy (Ukraine) \\ halyna.handzilevska@oa.edu.ua \\ https://orcid.org/0000-0002-6137-8344 \\ Olena Shershnova \\ Ph.D. in Public Administration, Senior lecturer \\ National University of Ostroh Academy (Ukraine) \\ olena.shershniova@oa.edu.ua \\ https://orcid.org/0000-0003-1582-4515

\section{Tetiana Chernous} \\ Postgraduate Student \\ National University of Ostroh Academy (Ukraine) \\ tetiana.chernous@ oa.edu.ua \\ https://orcid.org/0000-0003-4719-8256
}

\begin{abstract}
The abstract reveals the problem of the search of psychological stability resources of the person in poetic creativity by Wira Wowk in the poetry collection «Mandala». The results of content-analytical research and psycho-graphology analysis of the collection show a significant level of emotionality of the author's text and author's desire for inner balance during text creation as a process of finding psychological resources. According to the results of the analysis, it was also found that among the psychological resources of balance reflected in poetry there are such categories as: "aspiration of wisdom» (27.71\%), «self-confidence or assurance in own resources» (11.26\%) and «self-realization in profession» $(7.36 \%)$.
\end{abstract}

Key words: poetic collection «Mandala» by Wira Wowk, resilience, psychological resources, the algorithm of restoration of life creativity resources. 


\section{Вступ \\ Introduction}

Дослідження проблеми людського буття та гармонійного, збалансованого прояву особистості у світі, усе частіше науковці здійснюють крізь призму аналізу індивідуального способу творчої взаємодії з навколишнім середовищем. Однією 3 форм трансляції цього процесу $є$ текстова форма, що дозволяє організувати, осмислити та впорядкувати особистий досвід (Чепелєва, 2013). Актуальності у такому контексті набуває психолінгвістичний аналіз творів українських письменниківемігрантів, результати якого можуть допомогти пізнати різні стратегії адаптації до життєвих обставин, що слугують ресурсом для виживання. У сучасних умовах пошуку шляхів пристосування до пандемії ця проблема набуває неабиякого значення.

Мета дослідження - психолінгвістичний аналіз поетичної збірки «Мандаля» Віри Вовк у вимірі ресурсів резилієнсу.

\section{Методи та методики дослідження Methods and Techniques of the Research}

У межах комплексного дослідження було застосовано низку прикладних методів, зокрема, психографологічний аналіз та рейдовий контент-аналіз текстової сукупності - збірки «Мандаля» Віри Вовк. Методи дослідження $€$ взаємодоповнюючими для реалізації мети дослідження.

\section{Результати \\ Results}

Застосування означених методів дозволило виокремити психологічні ресурси резилієнсу авторки - безперервного, активного процесу, спрямованого на розвиток нових сил і ресурсів адаптації та відновлення (Гусак, 2017). Орієнтиром для цього слугував запропонований раніше алгоритм подолання бар'єрів стану внутрішньої рівноваги, спрямованого на розвиток інтелектуальних, духовно-моральних, творчих та емоційно-вольових якостей людини (Гандзілевська \& Кондратюк, 2021).

Результати дослідження $є$ репрезентативними для вибіркової сукупності, надійним та валідними, адже алгоритм побудови вибірки передбачає, що генеральна сукупність співпадає 3 вибірковою сукупністю та основою вибірки - збірка «Мандаля» Віри Вовк, яка включає 30 текстових блоків (поезій/ віршів). Категоріально, 3 огляду на семантику поезій, їх назви, які $є$ лаконічними та допомагають зорієнтувати читача на цілісність та розширення спектру залучання 
відчуттів до сприйняття текстової інформації, доцільно згрупувати за кількома категоріями, ранжованими за кількістю одиниць.

Загалом обсяг тексту становить 724 слова разом із заголовками (назвами поезій), а всього слів у власне аналізованому тексті (без заголовків) - 693, з яких 38.67\% становлять іменники, 6.35\% - займенники, заперечна частка «не» вживається у 7 поезіях «Герой», «Жебрак», «Мудрець», «Поет», «Покрова», «Свята корова», «Штукар».

Разом $з$ тим, за результатами психографологічного аналізу (Засєкіна \& Засєкін, $2008)$ доцільно стверджувати, що аналізований текст, де кількість речень становить 54, а їх середній розмір - 12,83 слів, характеризується достатнім коефіцієнтом логічної зв'язності $(0,92)$. Середній розмір речень від 6 до 28 слів (Табл. 1) свідчить про емоційність тексту авторки та їі прагнення до внутрішньої рівноваги під час текстотворення як процесу віднайдення ресурсів резилієнсу.

\section{Таблиця 1}

Ранжування середнього розміру речень у збірці «Мандаля» Віри Вовк

\begin{tabular}{|c|c|c|c|c|c|}
\hline Назва поезії & $\begin{array}{l}\text { Середній } \\
\text { розмір } \\
\text { речення, } \\
\text { кількість слів }\end{array}$ & Назва поезії & $\begin{array}{l}\text { Середній розмір } \\
\text { речення, } \\
\text { кількість слів }\end{array}$ & Назва поезії & $\begin{array}{l}\text { Середній } \\
\text { розмір } \\
\text { речення, } \\
\text { кількість слів }\end{array}$ \\
\hline Сльози & 6,00 & Молитви & 10,00 & Дзеркало & 14,50 \\
\hline Самурай & 6,67 & Блазень & 10,33 & Мандаля & 15,50 \\
\hline Глек & 7,33 & Мережальниця & 11,00 & Гора & 15,50 \\
\hline Кошики & 7,50 & Грішниця & 11,00 & Мудрець & 16,00 \\
\hline Швець & 7,50 & я & 11,00 & Коваль & 19,00 \\
\hline Річка & 8,00 & Свята корова & 11,50 & Штукар & 19,00 \\
\hline Воїн & 8,50 & Покрова & 12,00 & Сніжинка & 19,00 \\
\hline Рибалка & 9,00 & Вогонь-Дерево & 12,00 & Хмара & 21,00 \\
\hline Веселка & 9,00 & Звіздар & 13,50 & Жебрак & 23,00 \\
\hline Герой & 10,00 & Mope & 14,00 & Поет & 28,00 \\
\hline
\end{tabular}

Авторка тексту володіє значним словниковим запасом, адже коефіцієнт лексичної різноманітності (0.759), а емболія - відсутня. Середнє значення коефіцієнту агресивності (дієслівності) сукупності текстів збірки «Мандаля» складає 15.73.

В межах контент-аналізу одиниці відбору співпадають 3 одиницями аналізу і становлять смислові блоки, згруповані за п’ятьма категоріями «впевненість у собі/ у власних силах», «прагнення мудрості», «самореалізація у професії», а також «віра у добро», «допомога іншим», виокремлених згідно до праць О. Штепи (Штепа, 2016).

Категорію «впевненість у собі» відображають такі конструкти: «власну творчість двигнути», «Я йду під косою смерти / на повний зріст», «3 тим крамом, сказав, -/не бути моїй заслузі», «Із джерела річки, /вірна свойй породі, / плине 
безсмертна.» та вся поезія «Я» («Я в себе дома в княжій палаті/ та в хаті рибалки./Я їм золотою виделкою/ $i$ дерев'яною ложкою./Мені любі транатові вина /як і кринична вода. /Я ношу щчире намисто /на конопляній сорочці.»), «заки зруйнуєш ияарство, / забудуй себе», «Сльози за себе - / потоп і повінь», що становить $11.26 \%$ від загальної кількості слів (тексту).

Категорія «прагнення мудрості»: «кожний лад (береже) окрушину мудрости», «коли зустрінеш людину, / вдягни білу сорочку/й посади дерево», «тільки старий жебрак/ на порозі ще стариої святині - / то нині він найбагатший», "Я йду під гілкою в яблуках/ з похилим чолом», "Дід усміхнувся: “Байдуже, / коли кінчається глек, / щзо вірно носив людям воду. / Він буде ж ї̈ носити - з калиною й павою - / в легендах онуків”», «Коли докоряють, / ... то їм у відповідь/ молот відрешує / іскрами люті зорі», «Старий рибалка: «Виплинь по рибу», «людину міряють із середини», «По літах, лагідно, /бере в руку зморшку і сивий волос, /западає в утомлені очі: «Хто ти?», «Коли пустельник ішов / босоніж горі сповідатися, глибоким мовчаням / гора прощала провини.», «щ⿻ з давніх аварій/ відважним лишилися / фінікійські амфори», та всі поезії «Мудрець», «Сніжинка», «Молитви», що становить 27.71\% від тексту.

Категорія «самореалізація у професії»: «він пронизує всесвіт» («Звіздар»), «щеб стати майстром ипаги,/будь майстром гри мікадо» («Самурай»), «португальський кравещьь/вбиває кілки в закаблуки», «золотар/ викладає ијісарську корону / самоцвітами» («Швець»), «Та скоиюрблена / плетільниця мережок/нашпилених на подущині/кощавими пальц̧ями/намережала/пояс для земної кулі» («Мережельниця»), «коваль виковує аж до світанку/велетенські підкови» («Коваль»), «Юний рибалка ловив ичілу ніч/щ̧астя в золотих лусках» («Рибалка»), що становить 7.36\% від тексту.

Категорія «віри у добро» (9.24\% від тексту): «Покрова... / не питала, чи власна дитина», «Я продаю лиш кошики, доно, /задурно даю красу», «Сльози за других /дощ на посуху», «Мандарини надумав зрубати/сухе вогонь-дерево / навпроти пагоди,/але потім задумався/ $i$ зробив із нього пам'ятник», «Уздріли перед собою / грішницю, щуо стояла в повітрі / прозоріша, ніж пелюстка черешні», «Вона в затишку плакала / заки на сім барв зраділа. / То від сліз пронизаних сонцем/ веселка весела.», а також категорія «допомоги іншим» (2.45\% від тексту): «одягла негреня 3 передмістя», «Індіянка вчила дитину плакати», «Вогонь-дерево / дало свою кров на цввіт, / потім усохло». 


\section{Висновки \\ Conclusions}

Відтак, за результатами аналізу було встановлено, що серед відображених у поезіях психологічних ресурсів, що зумовлюють резилієнс людини, є такі категорії, як: «прагнення мудрості» (27.71\%), «впевненість у собі» (11.26\%) та «самореалізація у професії» (7.36\%), а також присутні компенсатори дисбалансу, що забезпечують духовно-моральну складову психологічної стійкості через категорії «віра у добро» $(9.24 \%)$ та «допомога іншим» (2.45\%). 3 огляду на те, що позитивна психологія розглядає здібності та особистісні властивості людини, як ціннісні та як допомогу в адаптації до стресових ситуацій (Штепа, 2016), то результати проведеного аналізу засвідчують, що збірка Віри Вовк «Мандаля»є прикладом текстів зорієнтованих на поновлення психологічних ресурсів читача (його резилієнсу) та відповідає алгоритму подолання бар'єрів стану внутрішнього балансу.

\section{Література References}

Вовк, В. (1980). Мандаля: тексти й витинанки. Ріо-де-Жанейро.

Гандзілевська, Г.Б., \& Кондратюк, В.В. (2021). Ресурси та бар'єри інформаційнопсихологічної безпеки вчителів початкових класів в умовах онлайн-навчання: резилієнс підхід. Наукові записки Національного університету «Острозька академія». Серія «Психологія», 12, 35-40.

Гусак, Н., та ін. (2017). Психосочіальна підтримка в умовах надзвичайних ситуацій: підхід резилієнс. Київ: Вид-во Національного університету «Києво-Могилянська академія», 92 с.

Засєкіна, Л.В., \& Засєкін, С.В. (2008). Психолінгвістична діагностика. Луцьк: РВВ «Вежа» ВНУ ім. Лесі Українки.

Чепелєва, Н. (2013). Розуміння та інтерпретація життєвого досвіду як чинник розвитку особистості. Кіровоград: Імекс-ЛТД.

Штепа, О.С. (2016). Психологічні ресурси як медіатор внутрішнього та зовнішнього «Я» людини. Проблеми сучасної психологї, 31, 559-568. 